\title{
Raised serum protein-bound iodine after topical clioquinol
}

\author{
A. C. UPJOHN \\ M.R.C.S., L.R.C.P.
}

General Practitioner, Ongar

\author{
H-J. B. Galbraith \\ M.D., F.R.C.P.
}

Physician, Chelmsford Hospitals

\author{
BETHEL SOLOMONS \\ M.D., F.R.C.P.I. \\ Dermatologist, Chelmsford Hospitals
}

RAISED serum levels of protein-bound iodine (PBI) in patients with normal thyroid function have been observed on many occasions after oral treatment with 5-chloro-7-iodo-8-hydroxyquinoline (iodochlorhydroxyquinoline, clioquinol, Enterovioform) (Thoren, 1960; Levin, Josephson \& Grünewald, 1966; Sonksen et al., 1968). It is less well appreciated that clioquinol administered topically can be absorbed in sufficient quantities to influence the PBI and the uptake of radio-active iodine by the thyroid gland.

\section{Case reports}

Case 1

Mrs G. F., aged 26, complained to her general practitioner (A. C. U.) of anxiety. There were some other clinical features suggesting thyrotoxicosis and the serum PBI was found to be $17.0 \mu \mathrm{g} / 100 \mathrm{ml}$ (normal, 3.5-8 $\mu \mathrm{g} / 100 \mathrm{ml}$ ). She was referred to a physician (H. -J. B. G.) in whose opinion she was euthyroid. A second PBI estimation was again raised at $11.0 \mu \mathrm{g} / 100 \mathrm{ml}$. It was then appreciated that for the previous $4 \frac{1}{2}$ months the patient had been applying Vioform-hydrocortisone cream to her hands as treatment for an exacerbation of chronic cheiropompholyx. This application was stopped and 14 days later the PBI was $6.8 \mu \mathrm{g} / 100 \mathrm{ml}$.

Three months later, after cessation of the local application, the PBI was $5.0 \mu \mathrm{g} / 100 \mathrm{ml}$. Vioformhydrocortisone treatment was applied again for $\mathbf{1 2}$ days although the cheiropompholyx was quiescent and the skin was intact. The PBI 9 days after restarting the application had risen to $8.4 \mu \mathrm{g} / 100 \mathrm{ml}$.

\section{Case 2}

Four months after Mrs S. H., aged 36, developed varicose dermatitis she started using Vioform-

Request for reprints: Dr H-J. B. Galbraith, Medical Academic Unit, Chelmsford and Essex Hospital, London Road, Chelmsford, Essex. hydrocortisone cream, and continued to do so for 17 weeks until her first out-patient visit to the skin department (B. S.). Apart from her varicose condition she complained of constant nervousness. Further examination revealed some signs of thyrotoxicosis. The PBI was $22 \mu \mathrm{g} / 100 \mathrm{ml}$. She stopped using the cream, and 3 weeks later her PBI was $5 \cdot 2$ $\mu \mathrm{g} / 100 \mathrm{ml}$. She agreed to use the cream again, and after 3 weeks, during which time she had used nearly three $20 \mathrm{~g}$ tubes, her PBI was $13.4 \mu \mathrm{g} / 100 \mathrm{ml}$. She then stopped using the cream and her PBI had returned to $5.0 \mu \mathrm{g} / 100 \mathrm{ml}$ a month later.

\section{Comment}

Vioform-hydrocortisone cream contains $3 \%$ clioquinol and $1 \%$ hydrocortisone in a water-soluble base composed of sodium lauryl sulphate, cetostearyl alcohol, spermaceti, glycerin, yellow soft paraffin, and water. The patients were using approximately 1.7 and $1.2 \mathrm{~g}$ of the ointment respectively daily, thus each day about $35-50 \mathrm{mg}$ of clioquinol was applied to the skin. Sonksen et al. (1968) gave $500 \mathrm{mg}$ clioquinol orally daily for 2 weeks to eight healthy subjects and found a mean PBI level at the end of this period of $118 \mu \mathrm{g} / 100 \mathrm{ml}$. The elevation of the PBI may be influenced by the length of treatment as well as the dose and it may be important that our patients had each been applying the drug for over 4 months.

Corticosteroids applied to the skin are absorbed to a varying extent depending on the concentration, the total dose, the anatomical site of the application, the pathological state of the skin, the solubility of the particular steroid used, the character of the vehicle, and the age of the patient (Scoggins \& Kliman, 1965; Sarkany \& Hadgraft, 1969; Feiwel, 1969). Using large doses (1200 mg daily) of $1 \%$ hydrocortisone with an occlusive dressing, Scoggins \& Kliman (1965) found that 'less than $10 \%$ of the dose was absorbed'. It seems probable from the findings 
in our two patients that a much higher proportion of the dose of clioquinol is absorbed.

Haskins, Luttermoser \& Brady (1950) investigated the absorption and distribution of iodine after the oral administration of clioquinol to rabbits and suggested that this drug was absorbed, and eliminated, without degradation and without the liberation of inorganic iodine having occurred to any great degree. In human studies using clioquinol labelled with radio-active iodine, Liewendahl \& Lamberg (1967) confirmed that a high proportion of the dose was absorbed from the gut. These workers also showed that, in rats, much of the drug was taken up by the thyroid gland in the unchanged form (Lamberg \& Liewendahl, 1967). Iodine derived from the clioquinol was rapidly incorporated into the iodotyrosine precursors of thyroid hormone. This latter observation may explain why, although clioquinol interferes with the thyroidal uptake of iodine (Henderson Smith, 1964), no case of hypothyroidism attributed to clioquinol therapy has been recorded. Another possible risk of treatment with this drug is retinal damage (Lancet, 1968). The present cases suggest that very long-term application of clioquinol to extensive skin lesions should be embarked upon with caution.

The high levels of PBI found after clioquinol treatment are due in part to protein-binding of the drug as well as to contamination of the serum by inorganic iodine (Liewendahl \& Lamberg, 1968). Although normal PBI levels were regained by our patients within 3 weeks of the cessation of treatment, the work of Thorén (1960), Levin et al. (1966), and Sonksen et al. (1968) suggests that this estimation is probably valueless as a test of thyroid function for at气 least 2 months after oral administration of clioquinol.

\section{References}

FIEWEL, M. (1969) Percutaneous absorption of topical $\overrightarrow{\vec{F}}$ steroids in children. British Journal of Dermatology, $81 \stackrel{+}{+}$ suppl. 4, 113.

HASKINS, W.T., LUTTERMOSER, G.W. \& BRADY, F.J. (1950)흐 The physiological disposition of Diodoquin, Vioform, and $\bar{\omega}$ Chiniform in the rabbit as determined with radioiodine. $\overrightarrow{\mathbb{D}}$ American Journal of Tropical Medicine, 30, 599.

HENDERSON SMITH, S.L. (1964) Drugs and investigations. British Medical Journal, 2, 1265.

LAMBerG, B.-A. \& LiewendahL, K. (1967) Transfer of the $\vec{\circ}$ iodine of the iodochloroxyquinoline molecule (Vioform) $\overrightarrow{\vec{H}}$ to the iodo-amino acids of the thyroid gland. Nuclear $\vec{\omega}$ Medizin, 6, 16.

LANCET (1968) Annotation-Clioquinol and other halo? genated hydroxyquinolines. i, 679.

LeVIN, K., JosephSON, B. \& GRUNewald, G. (1966) The" effect of iodochlorooxyquinoline and iopanoic acid on the $₹$ determination of PBI and BEI. Acta endocrinologicair Copenhagen, 52, 627.

LIEWENDAHL, K. \& LAMBERG, B.-A. (1967) Metabolism of $\mathrm{G}$ iodochloroxyquinoline in man. Nuclear Medizin, 6, 20.

LIEWENDAHL, K. \& LAMBERG, B.-A. (1968) Clioquinol and thyroid-function assessment. Lancet, ii, 979.

SARKANY, I. \& HADGRAFT, J.W. (1968) The influence offormulation on topical corticosteroid activity. British Journal of Dermatology, 81, suppl. 4, 98.

Scoggins, R.B. \& Kliman, B. (1965) Percutaneous absorp-tion of corticosteroids. New England Journal of Medicine, $\vec{v}$ 273, 831 .

SonkSEn, P.H., Ekins, R.P., Stevens, H.G., Williams, Es. \& NABARRO, J.D.N. (1968) Serum-levels of protein-bound iodine and thyroxine after a course of clioquinol. Lancet, ii, 425.

THOREN, A. (1960) The influence of iodide and iodized compounds on the PBI and the 131-I tracer test with specialo reference to various biologic states of the thyroid. Acta@ endocrinologica Copenhagen, 35, 351.

\title{
Metabolic alkalosis treated with intravenous hydrochloric acid
}

\author{
F. X. M. BEACH \\ M.B., Ch.B., M.R.C.P., D.T.M. \& H. \\ E. SHERWOOD JONES \\ Ph.D., F.R.C.P. \\ Intensive Care Unit and Clinical Pharmacology Unit (University of Liverpool) \\ Whiston Hospital, Prescot, Lancashire
}

IN CLINICAL practice, a severe metabolic alkalosis is found less frequently than a severe metabolic acidosis. In both disturbances the treatment consists of removing the cause and correcting the deficits or excesses in the body fluids. The severe metabolic acidosis of diabetic coma or that which follows cardiac arrest often needs urgent correction by giving sodium bicarbonate intravenously. In contrast, a metabolic alkalosis very rarely causes an immediate threat to life. In two patients recently admitted to this unit, the metabolic alkalosis required specific $\stackrel{N}{\sim}$ treatment with intravenous hydrochloric acid.

\section{Laboratory methods}

pH was determined electrometrically using $a$ ? capillary electrode (Siggaard-Andersen et al., 1960). The electrode was calibrated with two phosphate buffers of $\mathrm{pH} 7.416$ and 6.839 at $38^{\circ}$ (Semple, $\stackrel{+}{+}$ Mattock \& Uncles, 1962). The normal range was taken as $7 \cdot 35-7 \cdot 45$. 